Karol Łopatecki

Uniwersytet w Białymstoku

\title{
ITINERARIA JAKO ŹRÓDŁA POZNANIA MYŚLI STRATEGICZNEJ I OPERACYJNEJ W OKRESIE PANOWANIA STEFANA BATOREGO ${ }^{1}$
}

\author{
Itineraries as Sources of Knowledge about Strategic and Operational Thought \\ during the Reign of Stefan Batory
}

The article presents military itineraries, i.e. planned descriptions of the routes of troops. Such sources constitute the oldest objects of military cartography. They also enable reconstruction of strategic concepts and operational activities planned by commanders. The time of Stefan Batory was discussed in the article because such cartographic support was the basis for often quite complicated planning. Itineraries could be perfectly used both during mobilisation and relocation of the army, and also during military operations. They were especially useful in coordination of operations of two or more numbers of regiments or allied armies. Analysed examples suggest that at the time of the reign of Stefan Batory the early modern cartographic turn took place.

Keywords: cartography, itineraries, strategy, military science of the 16th century, operational activities, early modern cartographic turn

Słowa kluczowe: kartografia, itineraria, nauki wojskowe XVI w, strategia, działania operacyjne, wczesnonowożytny zwrot kartograficzny

Itineraria pojawiające się w XVI w. to wyjątkowy rodzaj źródła historycznego. Jak zauważyli Stanisław Alexandrowicz i Karol Buczek, są one najstarszymi obiektami, które można zaliczyć do zabytków kartografii wojskowej. Stanowią jednocześnie typ źródeł, które „odkrywają” przed badaczami koncepcję planowanych działań o cha-

\footnotetext{
${ }^{1}$ Artykuł powstał w ramach projektu badawczego Narodowego Centrum Nauki SONATA, nr 2016/23/D/HS3/03210 pt. Rewolucja militarna jako czynnik modernizacyjny skarbowości i organizacji państwa polsko-litewskiego na tle europejskim.
} 


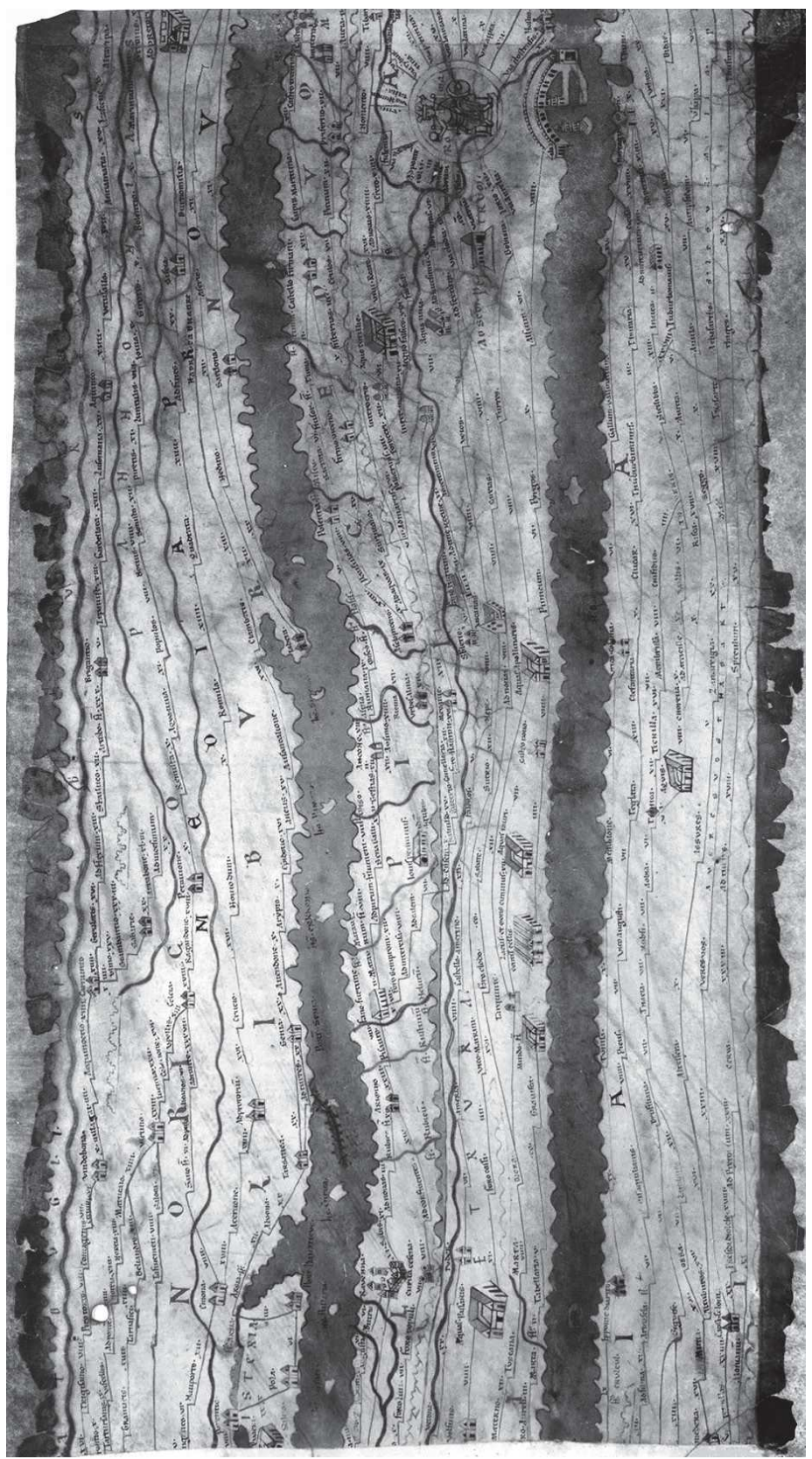

Il.1. Tabula Peutingeriana jako przykład wykonanych w starożytności itineraria picta ${ }^{2}$

2 Österreichische Nationalbibliothek (Wiedeń), Codex Vindobonensis 324; Tabula Peutingeriana, ed. K. Miller, Ravensburg 1887/1888 (facsimile). Całe itinerarium pictum zostało zdigitalizowane i udostępnione na stronie: https://upload.wikimedia.org/wikipedia/commons/5/50/TabulaPeutingeriana.jpg. 
rakterze operacyjnym i strategicznym³ ${ }^{3}$ Miały najczęściej formę tekstową, czasem tabelaryczną (itineraria annotata lub scripta ${ }^{4}$ ). Podawano w nich kolejne punkty podróży najczęściej wraz z odległością, a także ewentualnie uzupełniano dodatkowymi informacjami. Na wstępie należy podkreślić, że analogiczne opisy stosowane były zarówno na potrzeby wojskowe, jak i w celach dokumentujących peregrynacje, które stały się podstawą do bardziej rozbudowanych dzieł o tematyce chorograficznej ${ }^{5}$. Warto mieć również na względzie, że obecnie pod pojęciem itinerariów rozumie się krytyczne opracowania historyczne polegające na zestawieniu miejsc i dat pobytów danej osoby - najczęściej władców ${ }^{6}$.

Na potrzeby wojskowe itineraria zaczęto wykorzystywać już w armii Cesarstwa Rzymskiego ${ }^{7}$. 0 tym, że źródło to jest bardzo blisko ujęcia kartograficznego, świadczy fakt, iż już w starożytności powstawały na ich podstawie itineraria picta, czyli dzieła ikonograficzne, które ukazywały odległości dróg pomiędzy punktami (miastami), sam jednak układ przestrzenny był schematyczny i nie przedstawiał realnego obrazu terenu (zob. il. 1) ${ }^{8}$.

Itineraria odzwierciedlają przemiany, które możemy określić jako „wczesnonowożytny zwrot kartograficzny” (the early modern cartographic turn). Polegał on na

${ }^{3}$ S. Alexandrowicz, K. Buczek: Polska kartografia wojskowa do połowy XVII wieku, [w:] Dzieje polskiej kartografii wojskowej i myśli strategicznej. Materiały z konferencji, oprac. B. Krassowski, J. Madej: Warszawa 1982, s. 8. Warto przywołać głos w dyskusji Henryka Rutkowskiego: „itineraria pisane pełniły rolę map taktycznych, ale nie dawały obrazu kraju, który mógł się złożyć na całą sieć drożną". Tamże, s. 144. Sądzę jednak, że ustalenie trasy przemarszu ma ewidentnie charakter działań operacyjnych, a całość koncepcji wiąże się z czynnościami strategicznymi.

${ }^{4}$ S. Alexandrowicz: Kartografia wojskowa Wielkiego Księstwa Litewskiego do połowy XVII wieku, [w:] Kartografia wojskowa krajów strefy bałtyckiej XVI-XX w., red. S. Alexan d rowicz, Z. Karpus, W. Rezmar, Toruń 1996, s. 8.

${ }^{5}$ D. Rott: Staropolskie chorografie, Katowice 1995, s. 30-59, 88, 125-126, 134-139.

${ }^{6} \mathrm{P}$. Węco w ski: Polskie itineraria średniowieczne i nowożytne: przegląd badań i propozycje badawcze, „Studia Źródłoznawcze” R. 37: 2000, s. 14.

${ }^{7}$ F. Wegecjusz Renatus: Zarys wojskowości ksiąg cztery, oprac. i tłum. A.M. Komornicka: „Meander” 29 (1974), 4-5, s. 205: „Przede wszystkim więc dowódca musi mieć wierny i szczegółowy spis wszystkich dróg danej okolicy, gdzie toczy się wojna i dokładnie znać nie tylko odległości wyznaczone ilością kroków, ale i położenie gór i rzek i jakość dróg, krótszych, na przełaj i okrężnych. Prawdziwie przezorny wódz zaopatruje się w mapę sieci dróg , gdzie prócz wszystkich spisanych danych figuruje jeszcze wyrysowany plan części kraju mającej być terenem walk. W ten sposób jeszcze przed rozpoczęciem kampanii obmyśla on całą marszrutę mając całą okolicę przed oczami" (III.6).

${ }^{8}$ Przykładem jest Tabula Peutingeriana powstała około 300 r. n.e., której podstawą była mapa świata Marka Agrypy. W średniowieczu znane były dwie kopie, których istnienie odnotowano w 821/822 i 1265 r. Ostatecznie Tabula została wydana w Antwerpii w 1591 r. dzięki działaniom podjętym przez Konrada Peutingera. R.J.A. Talbert: Rome's World: The Peutinger Map Reconsidered,NewYork2010,s.10-68,133-139,162-165; Tabula Peutingeriana.CodexVindobonensis 324, Österreichische Nationalbibliothek, Wien, Kommentiert E. Weber, Graz 2004. Zob. http:// www.hs-augsburg.de/ harsch/Chronologia/Lspost03/Tabula/tab_intr.html. 
upowszechnieniu się myślenia przestrzennego opartego na wyobrażeniu pewnego obszaru na wzór coraz bardziej rozpowszechnionych map ${ }^{10}$. XVI-wieczny dowódca zaczyna myśleć i konstruować plany działań militarnych za pomocą mapy. To zrewolucjonizowało sposób prowadzenia wojen, gdyż umożliwiało dokładniejsze ulokowanie armii (oddziałów) w przestrzeni ${ }^{11}$. Dowódcy byli w stanie stworzyć w wyobraźni proste schematy oparte na wzorcu kartograficznym. Zaplanowane działania następnie przenosili na papier, czy to w formie szkiców, czy też poprzez opis drogi (itineraria). Tym samym zaczęto na poziomie strategicznym wykorzystywać i uwzględniać przestrzeń, co wpłynęło na kształtowanie się planowania operacyjnego $^{12}$.

W niniejszym artykule prezentuję typy itinerariów i dokonuję ich charakterystyki. Przede wszystkim ukazuje jak ten nowy instrument w rękach wodzów był wykorzystywany w czasach batoriańskich. Tym samym staram się odpowiedzieć na pytanie jak „wczesnonowożytny zwrot kartograficzny” wpłynął na sposób prowadzenia wojen w Rzeczypospolitej.

Do badań nad myślą strategiczną i operacyjną epoki nowożytnej szczególnie ważne są itineraria sporządzone przed, a nie podczas lub po wyprawie. Te drugie mają głównie cechę dokumentującą, choć w przyszłości mogły również służyć pomocą w czasie planowania kolejnych działań, gdyż w syntetyczny sposób przedstawiały ruch wojsk na danym terytorium ${ }^{13}$. Zupełnie inaczej wygląda sytuacja z pierwszym

${ }^{10} \mathrm{~W}$ zasadzie brak prac polskich dotyczących tego zagadnienia. Zjawisko to prezentuje w niepublikowanych dotychczas artykułach prof. Jakub Niedźwiedź. Wśród licznych książek sygnalizujących to zjawisko warto wyróżnić: T. Conley: The Self-Made map: Cartographic Writing in Early Modern France, Minneapolis-London 1997.

${ }^{11}$ Przekrojowe spojrzenie na kartografię wojskową w Europie: J. Hale: Warfare and Cartography, ca. 1450 to ca. 1640, [w:] The History of Cartography, vol. 3, part 1, Chicago 2007, s. 719-737; analiza ograniczona do Europy środkowo-wschodniej: Z.G. Török: Renaissance Cartography in East-Central Europe, ca. 1450-1650, [w:] tamże, s. 1839-1851; S. Al exa nd ro wicz, J. Łuczyński, R. Skrycki: Historia kartografii ziem polskich do końca XVIII wieku, Warszawa 2017, s. 228-244, 265-269.

${ }^{12}$ Pierwsze historyczne wyjaśnienie terminu „działania operacyjne” wiążą się z poglądami Henry'ego Humphreya Lloyda, który na bazie doświadczeń wojny siedmioletniej uznał je za „określoną formę działań prowadzonych przez samodzielne zgrupowania". Z punktu widzenia średniowiecznych i nowożytnych badań wojskowych jest to najprostsze, a równocześnie najbardziej pasujące do specyfiki epoki założenie. Dowódcy wszelkich wyodrębnionych organizacyjnie armii musieli podejmować decyzje dotyczących bieżącej działalności, co w pewnym uproszczeniu możemy mówić jako o sztuce manewrowania. Wypełniała ona ogromny obszar działań pomiędzy strategicznymi celami wojny opracowywanymi przez władcę, naczelnego wodza, radę wojenną, a działaniami taktycznymi związanymi z koniecznością przeprowadzenia bitew czy też działań oblężniczych. Por. J. Zieliński: Zarys teorii sztuki operacyjnej wojsk lądowych Rzeczpospolitej Polskiej, Toruń 1998, s. 22; H. Herman n: Operacyjny wymiar walki zbrojnej, Toruń 2004, s. 62; A. Polak: Sztuka wojenna. Kontekst teoretyczny i praktyczny, „Zeszyty Naukowe AON" 92 (2013), 3, s. 225.

${ }^{13} \mathrm{Z}$ czasów przedbatoriańskich ważne było itinerarium wykonane z wyprawy hetmana Jerzego Jazłowieckiego podjęte dla ochrony przed wojskiem tatarskim. „Żaden hetman nadeń 
typem źródła, na podstawie którego można odtworzyć koncepcję oraz myśl operacyjną i strategiczną naczelnego dowództwa. Oczywiście rozróżnienie jednej formy od drugiej może stanowić niemały kłopot. Często występująca różnica w źródłach dokumentujących przemarsz wojsk czy też dworu monarszego to znaczone obok miejscowości daty postoju ${ }^{14}$. W fazie planowania z reguły tak precyzyjne informacje (co dotyczy XVI i po części XVII w.) nie były uwzględniane ${ }^{15}$. Idealnym rozwiązaniem byłoby zestawienie planowanych działań operacyjnych z ich realizacją, dzięki czemu możliwym byłoby uwzględnienie bieżących decyzji wodzów wobec dynamicznie zmieniającej się sytuacji militarnej.

Itineraria, czyli opisowa charakterystyka szlaku, według którego miało ciągnąć wojsko, było pomocą z powodzeniem wykorzystywaną przez Zakon Krzyżacki już na przełomie XIV i XV w. Państwo zakonne gromadziło rozbudowane opisy dróg, którymi prowadzone były działania wojenne ${ }^{16}$. W Europie już około 1500 r. pojawiają się pierwsze drukowane mapy z zaznaczonymi drogami ${ }^{17}$.

Analogiczne materiały źródłowe wykonane w Koronie i Wielkim Księstwie Litewskim są późniejszej datacji. Najwcześniejsze przekazy zachowały się w dziale rękopisów Rosyjskiej Biblioteki Narodowej w Petersburgu, gdzie w kolekcji au-

ludzi więtszych przeciwko nieprzyjacielowi dalej nie wywiódł jako ten. A to było roku 1571". Zachowany spis wykonano od 16 V do 22 VII. B. Paprocki, Herby rycerstwa polskiego, wyd. K.J. Tu rows ki: Kraków 1858, s. 221-222.

${ }^{14}$ Zob. przykładowo: Opisanie traktu podrozy Jego Krolewskiey Mości z Warszawy do Grodna de anno 1784, Archiwum Główne Akt Dawnych, Zbiór Geograficzny Stanisława Augusta, sygn. 71-3, s. 1-7.

${ }^{15}$ Por. M. Wred e: Itinerarium króla Stefana Batorego 1576-1586, Warszawa 2010, s. 4344, przypis 79.

${ }^{16}$ Znanych jest ponad 100 opisów dróg wykonanych w latach 1384-1402. Die Littauischen Wegeberichte, [w:] Scriptorus Rerum Prussicarum, red. T. Hirsch, M. Töp pen, E. Strehlke Bd. II, Leipzig 1863, s. 662-708; por. V. Al mo naitis: Laukuvos apylinkés kryžiuočiu karo keliu aprašymu duomenimis, [w:] Laukuva. Lietuvos valsčiai I, Vilnius 2005, s. 171-183; M. Rad och: Die littauischen Wegeberichte jako źródło wiedzy geograficznej w Zakonie Krzyżackim o ziemiach Wielkiego Księstwa Litewskiego, [w:] Nauki pomocnicze historii. Teoria, metody badań, dydaktyka, red. A. Jaw or ska, R. Jo p, Warszawa 2013, s. 263-271; K. Kwiatkows ki: Wojska zakonu niemieckiego w Prusach 1230-1525 (korporacja, jej pruskie władztwo, zbrojni, kultura wojny i aktywność militarna), Dzieje Zakonu Niemieckiego, t. 3, Toruń 2016, s. 267, 269. Formę rozbudowanego opisu drogi ma relacja Ludwika Nakera, która przedstawia podróż posiłkowego wojska zakonnego zmierzającego do Mołdawii w 1497 r. X. Liske, Cudzoziemcy w Polsce, Lwów 1876, s. 7-22; Liborius Naker's Tagebuch, red. M. To e pp en, [w:] Scriptores Rerum Prussicarum, Bd. 5, Leipzig 1874, s. 289-314.

${ }^{17}$ Są to dwie prace: Erhard Etzlaub, Erstausgabe der Romwegkarte oraz Giovanni Pontano, Vera, et integra limit. Regni Neapolitani Mappa Topo. Ferdinandi Regis jussu mensurata ... studio et opera Joan. Jov. Należy nadmienić, że Etzlaub objął swoją mapą również ziemie śląskie. B. Englisch: Erhard Etzlaub's Projection and Methods of Mapping, "Imago Mundi" 48 (1996), s. 103-123; L. Bag row, History of Cartography, New Brunswick-London 2010, s. 93; R. Wytyczak: Śląsk $w$ dawnej kartografii. Obraz Śląska na mapach XVI-XVIII wieku w zbiorach Zakładu Narodowego im. Ossolińskich we Wrocławiu, Wrocław 1998, s. 18-19. 
tografów Piotra Dubrowskiego przechowywane są materiały gromadzone przez Radziwiłłów $^{18}$. Najstarsze dwa źródła dotyczą panowania Zygmunta II Augusta. Pierwszy zatytułowany Droga Je[go] K[rólewskiej] Mosczi, obejmują miesiąc wrzesień bez adnotacji rocznej (zob. il. 2) ${ }^{19}$. W opisie archiwalnym wskazano, że trasa rozpoczynająca się w Malborku, a kończąca w Wilnie dotyczy podróży Zygmunta Augusta w 1570 r. Po zestawieniu podanych tam informacji z itinerarium władcy polsko-litewskiego wykonanym przez Antoniego Gąsiorowskiego okazuje się, że data dokumentu jest błędna. Przedstawiona droga odnosi się do roku $1552^{20}$. Warto podkreślić, że źródło to pozwala na znacznie dokładniejsze zestawienie miejsc postojowych ostatniego Jagiellona, niż to zostało wykonane w powyższej publikacji ${ }^{21}$. Co oczywiste, odnotowane zostało faktyczne ciągnienie dworu, nie zaś plan podróży, co widoczne jest poprzez wymienienie miejscowości przy każdym dniu ${ }^{22}$. Rzuca się w oczy fakt, że w tym dokumencie nie określono odległości pomiędzy miejscami postojowymi. Uważam, że posiadanie przez Radziwiłłów intinerarium dworu królewskiego mogło stanowić inspirację do wykonywania podobnej dokumentacji na potrzeby wojskowe, tym bardziej, że wybór drogi dla króla i całego orszaku był przemyślanym działaniem dostosowanym m.in. do struktury własności ziemskiej (królewszczyzny, dobra zakonne) ${ }^{23}$.

Drugi, z mojej perspektywy badawczej ciekawszy dokument zatytułowany jest Wiadomość kędy w ziemię nieprzyjacielskq iść (zob. il. 2) 24. Został on wykonany na potrzeby wojsk litewskich około $1570 \mathrm{r}^{25} \mathrm{Ma}$ on charakter planowanych, ewentualnie możliwych tras przemarszu. Itinerarium przedstawia dwie drogi. Pierwsza, to

${ }^{18}$ K. Ko ss arze wski, S. Szyll er: Rękopisy Biblioteki Załuskich w Sankt Petersburgu, „Rocznik Biblioteki Narodowej" t. 44: 2013, s. 254.

${ }^{19}$ Российская национальная библиотека, Санкт-Петербург, Ф. 971, Авт. 321/1, № 3, k. 6.

${ }^{20}$ A. Gąsi orow s ki : Itineraria dwu ostatnich Jagiellonów, „Studia Historyczne” t. 16: 1973 nr 2, s. 269.

${ }^{21}$ We IX 1552 r. Zygmunt August znajdował się w następujących miejscowościach: Malbork (1-7), Elbląg (8), Frombork (9), Siekiercze (10), Brandenbork (11), Królewiec (12-14), Tapiewo (15), Taplaki (16), Jurzenbork (17), Kropiski (18), Ragneta (19-20), Swaba (21), Jurbork (22), Wielona (23), Wilika (24), Kowno (25-26), Ziszmury [prawdopodobnie Żyżmory] (27), Siemieliszki (28), Troki (29), Wilno (30). Российская национальная библиотека, Санкт-Петербург, Ф. 971, Авт. 321/1, № 3, k. 6.

${ }^{22}$ Często itineraria królewskie łączono w jednej pozycji z wydatkami poniesionymi na postojach. Zob. A. Gąsio rows ki: op. cit., s. 256-257; Provisio stationum S. Mtis R. in itineribus a finibus regni eunte sua Mte ex Transilvania in regnum Poloniae, [w:] Księgi podskarbińskie z czasów Stefana Batorego 1576-1586, cz. 1, wyd. A. Pawiński: Warszawa 1881, s. 54-59; Distributa in sumptum provisionis stationum S. M. R., [w:] Tamże, s. 182-188.

${ }^{23}$ A. Gąsiorowski: op. cit., s. 252-253, 257; D. Wrede, op. cit., s. 43-44, 110 (przypis 194).

${ }^{24}$ Российская национальная библиотека, Санкт-Петербург, Ф. 971, Авт. 321/1, № 2, k. $5-5 \mathrm{v}$.

${ }^{25}$ Za datowaniem, obok adnotacji archiwalnej przemawia również filigran, który możemy wiązać z rokiem 1569. S. Alexa nd ro wi cz: Kartografia Wielkiego Księstwa Litewskiego od XV do połowy XVIII wieku, Warszawa 2012, s. 170. 
daleka wyprawa idąca pod Psków. Prowadzić ona miała od Kiesi przez Smiltyń, Kierepeć, Nowogródek Inflancki, aż do Monasteru Pskowsko-Pieczerskiego, w drodze powrotnej zaś do Dorpatu i Walk. Drugi szlak jest znacznie krótszy i obejmuje kierunek północno-zachodni. Z Kiesi wyprawa miała prowadzić przez Kermissę, Burtniki, Pirkieł, Salę, a w drodze powrotnej aż do Dyjamentu (Dźwinoujścia). Źródło wbrew tezie powtarzanej w literaturze nie jest jednak ogólnikowe ${ }^{26}$. Faktycznie brakuje w dokumencie odległości pomiędzy punktami, za to droga uwzględnia uwarunkowania terenowe (lasy, brzeg morski, a także trakt wielki, itp.).
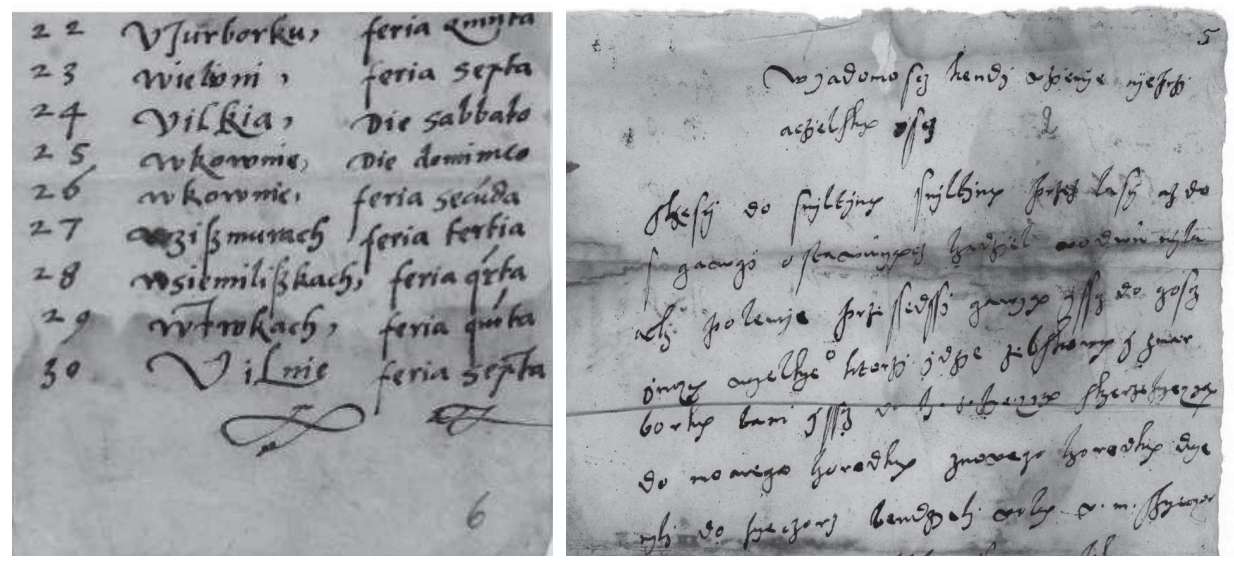

Il. 2. Dwa rodzaje itinerariów (fragmenty) - po lewej ukazana droga przemarszu, po prawej opis drogi możliwej do wykorzystania przez wojsko ${ }^{27}$.

Wiadomość kędy w ziemię nieprzyjacielska iść jest bardzo wartościowym źródłem przy badaniu rozwoju myśli strategicznej i operacyjnej w epoce nowożytnej. Jest to bowiem najstarszy materialny ślad po działaniach koncepcyjnych dowództwa, które mogły być wykorzystane na potrzeby prowadzonych kampanii wojennych oraz do działań rozpoznawczych ${ }^{28}$. 0 tym, że źródła te stawały się podstawą narad wojskowych przedstawił w wotum sejmowym 1624 r. Tomasz Zamoyski. Przywołał on dwie postacie, swego ojca - Jana (zm. 1605) i Stanisława Żółkiewskiego (zm. 1620). Wodzowie ci mieli sporządzone itineraria, które pozwalało podjąć ofensywną wyprawę przeciwko Chanatowi Krymskiemu („któremiby w tamten kraj wojsko nasze

\footnotetext{
${ }^{26}$ S. Al exand rowicz: Rozwój kartografii Wielkiego Księstwa Litewskiego od XV do połowy XVIII wieku, Poznań 1989, s. 192; tenże, Kartografia Wielkiego Księstwa Litewskiego, s. 170.

27 Российская национальная библиотека, Санкт-Петербург, Ф. 971, Авт. 321/1, № 2, k. 5-5v; Российская национальная библиотека, Санкт-Петербург, Ф. 971, Авт. 321/1, № 3, k. 6.

${ }^{28}$ Jan Zborowski w 1570 r. wydając artykuły wojskowe, zobowiązywał starostów inflanckich do działań wywiadowczych, tak aby „jeśli by się co nowego (...) przydało abo wsczynało i tego przestrzegać aby się żadne ubliżenie w państwach Je[go] Kró[lewskiej] M[iłoś]ci za granicą niedziały". Российская национальная библиотека, Санкт-Петербург, Ф. 971, Авт. 321/1, № 152, k. 2v, art. 3.
} 
brevi compendio iść mogło"). Podczas planowania zwracano uwagę nie tylko na wybór najszybszej trasy, lecz także ich przepustowość („,w których się dwa wozy przeciw sobie minąć nie mogą"), uwzględniano także szlaki zaopatrzenia ${ }^{29}$.

Istotnym impulsem do tworzenia z góry zaplanowanych tras przemarszu wojsk wiązać należy z koniecznością operowania na jednym obszarze kilku armii sojuszniczych lub samodzielnych pułków. Zjawisko to pojawiło się podczas pierwszej wojny północnej, kiedy do Inflant wkroczyła armia koronna i litewska ${ }^{30}$. Tym samym pojawiła się konieczność koordynacji działań. 0 pierwszych próbach świadczy list hetmana zaciężnego koronnego Floriana Zebrzydowskiego do hetmana wielkiego litewskiego Mikołaja Radziwiłła „Rudego” z 1562 r. W niej dowódca polski pisze o trasie przemarszu swojej armii i o możliwości spotkania się obu wodzów. „Ja ciągnę tą drogą z Połocka na Trośnice, na Domniki, na Rowne, na Kozjany, na Turobczą, na Uskotę, gdziem dziś jest, 8 mil od Ozierzyszcz, a pociągnę na Wierowlią, na Nowosiełki, na Świeżydowice"31. Oznacza to, że nie tylko punkt docelowy był ustalony, lecz sojusznicza armia ze znacznym wyprzedzeniem wiedziała o kolejnych etapach trasy. Kilka dni później, kiedy wojska koronne dotarły już do Jezierzyszcz (Ozierzyszcz), Zebrzydowski otrzymał list od Radziwiłła, „z któregom wyrozumiał, iż W.M. raczyłeś się ruszyć z wojskiem swym ku Witebsku, a z Witebska będziesz raczył sam ku Ozieszyszczu ciągnąć" ${ }^{\prime 2}$. Ta wymiana informacji dobitnie świadczy o próbach wprowadzenia koordynacji w podejmowanych działaniach na szczeblu działań operacyjnych i strategicznych.

Wprowadzenie itinerariów miało jedną zasadniczą wadę. Planowana trasa armii mogła dostać się w ręce nieprzyjaciela. W świetle renesansowych teoretyków i praktyków sztuki wojennej, dokładną marszrutę należało planować z zaledwie dziennym wyprzedzeniem, co kontrolowałoby przepływ informacji i uniemożliwiałoby wrogowi podejmowania działań utrudniających pochód armii ${ }^{33}$. Itineraria właściwie uniemożliwiały realizację tego postulatu.

${ }^{29}$ S. Żu rkows ki : Żywot Tomasza Zamojskiego kanclerza W. Kor., wyd. A. Batowski, Lwów 1860, s. 200.

${ }^{30}$ G. Les maitis: Wojsko zaciężne w Wielkim Księstwie Litewskim w końcu XV-drugiej połowie XVI wieku, tłum. B. Piasecka, Warszawa 2013, s. 52-68, 78-88.

${ }^{31}$ F. Zebrzydowski do M. Radziwiłła „Rudego”, obóz pod Uskołami 12 VIII 1562, [w:] Memoriał do działalności wojskowej Floriana Zebrzydowskiego, „Przegląd Historyczno-Wojskowy” t. 9: $1937 \mathrm{nr} 2$, s. 290.

${ }^{32}$ F. Zebrzydowski do M. Radziwiłła „Rudego”, obóz pod Jezierzyszczami 21 VIII 1562, [w:] Tamże, s. 291.

${ }^{33}$ Die Kriegsordnung des Markgrafen zu Brandenburg Ansbach und Herzogs zu Preussen Albrecht des Älteren - Königsberg 1555, t. I, red. von. H. J. Bömelburg, B. Chiari, M. Th o mae, Braunschweig 2006, s. 209-210; J. Tarn owski: Consilium rationis belicae, oprac. T.M. Nowak, Warszawa 1987, s. 79; M. Biels ki: Sprawa rycerska, [w:] Archiwum domowe do dziejów literatury krajowej, wyd. K.W. Wój ci cki: Warszawa 1856, s. 290. 
Najbezpieczniejsze było używanie opisów drogowych podczas czynności mobilizacyjnych. Itineraria zaczęto stosować już na potrzeby koncentracji wojsk przed wyprawą na Połock w 1579 r. Wówczas Stefan Batory przygotował dla zaciągniętych oddziałów trasę przemarszu. W informacji adresowanej do hetmana Mikołaja Radziwiłła zezwalał na ewentualną zmianę zaproponowanej trasy, poprawki powinny jednak zostać dostarczone do króla w celu ich akceptacji ${ }^{34}$. Warto podkreślić cel takiego działania. Otóż oddziały powinny poruszać się w miarę możliwości odrębnymi szlakami, tak aby miejscowości były równomiernie obciążone kwaterunkiem wojsk. Wprost odnotowano to $\mathrm{w}$ anonimowej cedule (list prawdopodobnie nie zachował się), w której informowano jednego z Radziwiłłów będącego hetmanem (Mikołaja lub Krzysztofa „Pioruna”) o planowanym ciągnieniu wojsk koronnych przez terytorium Wielkiego Księstwa Litewskiego. Powinno się ono odbyć różnymi drogami dla poszczególnych oddziałów lub pułków, upoważniono przy tym księcia do zmiany wyznaczonych tras, co w domyśle wynika z lepszej znajomości terenu.

Cziągnienie liudzi służebnych polskich wedlia miesc na których ma lieża, ślię do WM. aby nie jedną drogą cziągneli, bo się wyżywić nie mogą, a ktemu i to scziągającz się jeden do drugiego nie liada by drogę uczynił. Przetho z wolie Kro. Jeo Mści szlię regestr do WMści drogi cziągnienia naznaczonej kędy mają cziągnąć, który wedlia zdania swego racz W.M. poprawić, kędy by naproścziej i nalepiej zdało by się waszej Książeczej Mści. A gdzie na ten czas lieże posyłam WMści regestr, tak jako mi dano znać o swowolne Ich Mci wjachaniu w granicze W. X. Lit. ${ }^{35}$

Podobna sytuacja miała miejsce w 1582 r., kiedy to oddziały koronne miały wyruszyć na Podole, w poprzednim zaś roku zostały rozłożone na Podlasiu i w okolicznych ziemiach. Jan Zamoyski, organizując tę wyprawę, zapowiedział

żeby i ludzie w dodawaniu żywności wszelakiej panom żołnierzom barzo utrapieni i uciążeni nie byli, i ludziom żołnierskim żeby nie przychodziło z trudnością wielką w ciągnieniu żywności dostawać, tedy wszystko wojsko na trzy półki rozdzielony być ma, z których każdy osobnem niżej opisanem gościńcem ciągnąc będzie aż do leży swych.

Hetman pierwszemu pułkowi, dowodzonemu przez kasztelana warszawskiego Wojciecha Ręczajskiego, nakazał zgromadzić się do Bielska i poruszać się według trasy: Siemiatycze - Janów - Kodeń - Włodawa - Świerze - Hrodło - Włodzimierz Łuck. Pułk ten został dodatkowo podzielony na dwie części, które miały podróżować w odległości dnia drogi po tej samej trasie. Drugi pułk miał ściągnąć do Szereszowa, a jego trasę zaplanowano przez: Kamieniec Litewski - Brześć Litewski - Torczym, - Łuck. Ostatni pułk podążać miał od Słonimia poprzez: Sielce - Kobryń - Ratno

${ }^{34}$ Stefan Batory do M. Radziwiłła, Warszawa 18 I 1579, [w:] Sprawy wojenne króla Stefana Batorego. Diariusze, relacje, listy i akta z lat 1576-1586, wyd. I. Polkowski, Kraków 1887, s. 155.

${ }^{35}$ Российская национальная библиотека, Санкт-Петербург, Ф. 971, Авт. 321/1, № 222. 
- Niesuchojcze - Sokolia - Rozycz. W tym przypadku również pułk został podzielony na dwie części ${ }^{36}$. Z powyższych danych wynika, że podział na pułki miał przede wszystkim ułatwić aprowizację oraz przyśpieszyć ciągnienie wojska.

Wyodrębnienie pułków z armii było korzystne również pod względem stricte militarnym, co oczywiście musiało wiązać się z wykorzystaniem itinerariów. Najstarszy przykład takiego zastosowania pochodzi z początku 1579 r. Świadczy o tym niepozorna, niewielka karteczka przechowywana w Autografach Dubrowskiego w Bibliotece Narodowej w Petersburgu (zob. il. 3). Stanowi ono planowaną marszrutę wojsk z Kiesi do Dorpatu. Zachowany opis dróg jest cenny z dwóch powodów. Po pierwsze wskazuje, że Krzysztof Radziwiłł „Piorun” zaplanował wydzielenie trzech pułków (prawy, centralny i lewy), każdy zaś z nich miał przygotowane trzy różne trasy. Wszystkie one miały wyruszyły z Kiesi (Wenden), a punktem docelowym był Dorpat. Po drugie odnotowano dokładnie (w milach) odległości między poszczególnymi miejscowościami, co pozwalało na koordynację działań poszczególnych pułków ${ }^{37}$.

Oceniając to itinerarium zadziwia precyzja wykonanych tras, które prawidłowo ukazują rzeczywiste rozmieszczenie poszczególnych miast i zamków ${ }^{38}$. Dostrzec można, że szlak lewy i środkowy był w zasadzie do siebie równoległy. Zapewniało to możliwość dokonania większych zniszczeń, przy pozostawaniu w stałej łączności. Oba pułki powinny pod Dorpat dotrzeć tego samego dnia. Natomiast szlak prawy już podczas prac koncepcyjnych miał dwukrotnie dłużą, samodzielną trasę. Pułk podążający tą trasą miał na celu znaczne poszerzenie zniszczeń pogranicza, a jednocześnie dezorganizację obrony wojsk rosyjskich. Głęboka rejza w terytorium moskiewskie od południa, mogła przynieść i przyniosła oczekiwane rezultaty. Tym samym wyodrębnienie trzech pułków wiązało się z pogłębioną myślą strategiczną i operacyjną.

Podział na trzy pułki zakończył się sporym sukcesem. Krzysztof Radziwiłł prowadząc pułk centralny i lewy dokonał spustoszeń okolic Dorpatu ${ }^{39}$. W tym czasie

${ }^{36}$ Porzadek ciagnienia na Podole, artykuły hetmańskie, Bielsk 27 VI 1582, [w:] Archiwum Jana Zamoyskiego kanclerza i hetmana wielkiego koronnego, t. III: 1582-1584, wyd. J. Siemieńs ki: Warszawa 1913, s. 460-462.

${ }^{37}$ Российская национальная библиотека, Санкт-Петербург, Ф. 971, Авт. 321/1, № 9, k. 8.

${ }^{38}$ Szerzej analizuję tę wyprawę w pracy: K. Ło patecki: Wyprawa Krzysztofa Radziwiłła do Inflant zima 1579 r. Z badań nad kartografiq wojskowa XVI wieku , „Zapiski Historyczne” 83 (2018), 1, s. 39-67.

${ }^{39}$ Ogólnie o wyprawie tej: M. Fe re nc: Mikołaj Radziwiłł „Rudy”(1515-1584), Kraków 2008, s. 574-575; P. Łab ęd ź: Działalność wojskowa Krzysztofa Radziwiłła „Pioruna” w latach 15721579, „Zapiski Historyczne” t. 76: $2011 \mathrm{nr}$ 1, s. 36-37; H. Kotarski: Wojsko polsko-litewskie podczas wojny inflanckiej 1576-1582. Sprawy organizacyjne. Część II, „Studia i Materiały do Historii Wojskowości" 17 (1971), 1, s. 74-75; D. Kupisz: Połock 1579, Warszawa 2003, s. 98-99; T. Korzo n: Dzieje wojen i wojskowości w Polsce, t. II, Kraków 1912, s. 33; H. Lule wi cz: Radziwiłł Krzysztof zwany Piorunem, [w:] Polski słownik biograficzny, t. XXX, Wrocław 1987, s. 264-276; M. Plewczyń s ki: Wkład Radziwiłłów w rozwój staropolskiej sztuki wojennej XVI w., 
niespodziewający się niczego Rosjanie zostali zaskoczeni w położonym o $80 \mathrm{~km}$ od Pskowa zamku Kierepeć przez trzeci pułk dowodzonych przez obersta Jürgena Buttlera. Twierdza została zdobyta, wzięto jeńców, po czym spalono umocnienia i po połączeniu wszystkich pułków powrócono do Kiesi ${ }^{40}$.

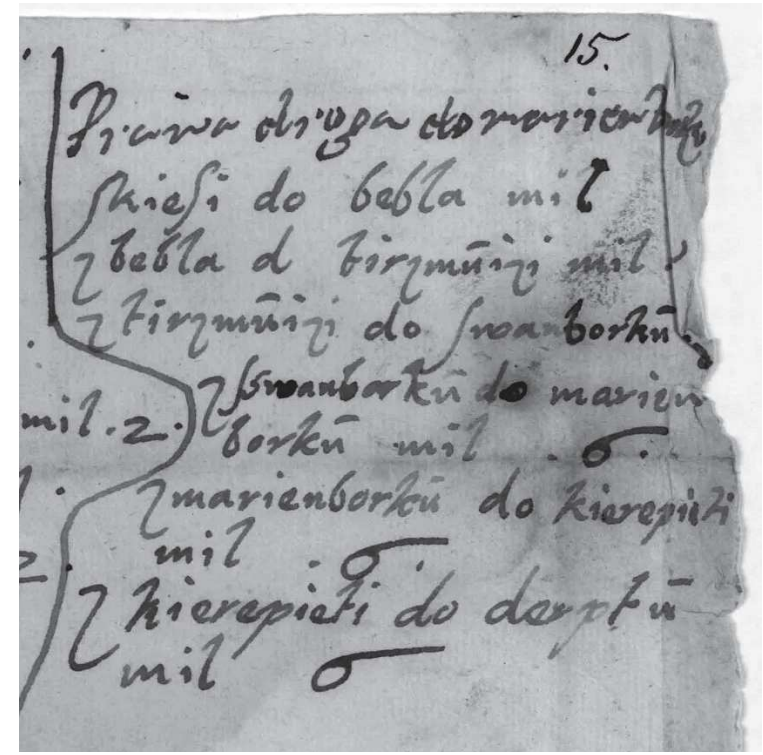

Il. 3. Itinerarium przygotowane na potrzeby wyprawy na Dorpat wykonane przez Krzysztofa Radziwiłła „pioruna” zimą 1579 r. (fragment prezentujący przemarsz pułku „prawego”) ${ }^{41}$.

Elity wojskowe Rzeczypospolitej zaczęły śmielej stosować itineraria jako pomoc przy planowaniu działań wojennych. Poświadcza to wydarzenie o kilka miesięcy późniejsze. W dniach 12-18 lipca 1579 r. król wraz z najwyższymi dostojnikami i dowódcami stacjonował w oddalonym o 80 km od Wilna Świrze. Odbyła

„Miscellanea Historico-Archivistica” 7 (1997), s. 33-34. Autorzy nie znali jednak tego źródła, nie formowali więc hipotezy o wydzieleniu trzech pułków, a zdobycie zamku przypisywano w sposób bezpośredni Krzysztofowi Radziwiłłowi „Piorunowi”.

${ }^{40}$ T. Hiärn: Ehst-, Lyf- und Lettlaendische Geschichte, red. C.E. Napiersky, Riga-DorpatLeipzig 1835, s. 323. B. Rüssow, Livländische Chronik: Aus dem Plattdeutschen übertragen und mit kurzen Anmerkungen versehen durch Eduard Pabst, Rewal 1845, s. 272: „Kiriempe verbrannt, 1579. Auf dasselbige Mal ist Jürgen Butler auch mit den Curischen und Stiftischen von Riga in's Stift Dörpte gefallen und hat das Häuslein Kiriempe gestürmt, etliche Russen darauf erschlagen und dasselbige Haus in den Grund verbrannt"; B. Rus sovven: Chronica. Der Provintz Lyfflandt, darinnne vermeldet werdt, [b.m.w.] 1584, s. 117; F.F. von Fircks: Ueber den Ursprung des Adels in den Ostsee-Provinzen Russlands und das den alten Rittergeschlechtern daselbst gebührende Prädicat Freiherr, Mitau-Leipzig 1843, s. 148; A. Seraphim: Die Geschichte Des Herzogtums Kurland (1561-1795), Reval 1904, s. 30-31; C. Mettig: Baltische Städte: Skizzen aus der livländischen Geschichte, Riga 1901, s. 9.

${ }^{41}$ Российская национальная библиотека, Санкт-Петербург, Ф. 971, Авт. 321/1, № 9, k. 8. 
się wówczas narada, która zdecydowała o podjęciu decyzji w ujęciu strategicznym, a następnie operacyjnym ${ }^{42}$. Według Reinholda Heidensteina podczas rady wojennej „Litwini prawie wszyscy oświadczyli się za tem, żeby iść na Psków przez Inflanty”43. Informacja taka wskazuje, że elity Wielkiego Księstwa Litewskiego miały nie tylko koncepcję strategiczną, lecz także przygotowany plan działania operacyjnego - konkretną trasę przemarszu prowadzącą przez obszar Inflant. Rzeczywiście w dokumentacji po Radziwiłłach „birżańskich” znajdujemy itineraria, które uwzględniały trasy przemarszu prowadzące z Inflant do Pskowa. Plan taki zachował się w dwóch egzemplarzach (k. 18-18v, 20-20v i 19-19v) i był on zatytułowany Droga do [ziemi] moskiewskiej ${ }^{44}$. Stanisław Aleksandrowicz utożsamiał te itineraria z rokiem $1581^{45}$. Tymczasem sama współcześnie wykonana adnotacja archiwalna odnotowuje anno 157946. Wszystko wskazuje, że w Świrze Mikołaj Radziwiłł przedstawił Batoremu opisany przez Heidensteina plan przemarszu do Pskowa przez terytorium Inflant. Przewidywana koncepcja miała polegać na skierowaniu się do twierdzy Kokenhauzen, a następnie do granicy moskiewskiej (12 mil), Ostrowa (8 mil) i Pskowa (12 mil $)^{47}$. Ostatecznie przyjęto koncepcję Stefana Batorego, który forsował i przygotował projekt ataku na Połock i zajęcia całej Połocczyzny.

Generalnie podział na pułki zawsze wiązać się powinien ze stworzeniem itinerariów, które koordynowałyby operacje całej armii. Takie działanie było stosowane podczas trzech wypraw Stefana Batorego na Moskwę, co wynikało z potrzeby sprawnej komunikacji gigantycznych, kilkudziesięciotysięcznych armii (wyprawa pod Połock - 41 814; Wielkie Łuki - 48 399; Psków - 47000 żołnierzy ${ }^{48}$ ). Wyodrębnienie oddzielnych zgrupowań wojskowych miało istotne walory operacyjne i stra-

\footnotetext{
${ }^{42}$ M. Ferenc: dz. cyt., s. 577-578; M. Wrede, op. cit., s. 98-99.

${ }^{43}$ R. Heid en stein: Pamiętniki wojny moskiewskiej w 6 księgach, wyd. i tłum. J. Czubek, Lwów 1894, s. 42; tenże, Dzieje Polski od śmierci Zygmunta Augusta do roku 1594, t. I, tłum. M. Gliszczyński, Petersburg 1857, s. 305-306; por. M. Bielski: Kronika polska, wyd. J. Bielski, Kraków 1597, s. 760-761.

${ }^{44}$ Российская национальная библиотека, Санкт-Петербург, Ф. 971, Авт. 321/1, № 11, k. 18-20.

${ }^{45}$ S. Alexandrowicz: Rozwój kartografii, s. 193; tenże, Kartografia Wielkiego Księstwa Litewskiego, s. 170.

${ }^{46}$ Trzeba odnotować, że zachowały się itineraria z 1581 r., które są już bardzo przemyślanym i szczegółowym planem działania nieporównywalnym do tych zaproponowanych w 1579 r. Российская национальная библиотека, Санкт-Петербург, Ф. 971, Авт. 152, № 4, k. 15.

${ }^{47}$ Российская национальная библиотека, Санкт-Петербург, Ф. 971, Авт. 321/1, № 11, k. $18 \mathrm{v}-19,20$.

${ }^{48}$ H. Kotarski: Wojsko polsko-litewskie. Część II, s. 105; tenże, Wojsko polsko-litewskie podczas wojny inflanckiej 1576-1582. Sprawy organizacyjne. Część III, „Studia i Materiały do Historii Wojskowości" t. 17: $1971 \mathrm{nr} 2$, s. 108; idem, Wojsko polsko-litewskie podczas wojny inflanckiej 1576-1582. Sprawy organizacyjne. Część IV, „Studia i Materiały do Historii Wojskowości" t. 18: $1972 \mathrm{nr} 1$, s. 39.
} 
tegiczne podczas drugiej wyprawy, której celem były Wielkie Łuki. Pod Witebskiem wyodrębniono z głównych sił prawą kolumnę pod dowództwem Jana Zamoyskiego, która rozpoczęła marsz 29 lipca. Jej celem było zdobycie Wieliża, następnie Toropca, po czym skierowanie się do Wielkich Łuk. Pierwszy etap podróży zakończył się 3 sierpnia, a tego dnia główne siły Batorego ruszyły trasą Suraż - Uświat - Wielkie Łuki. Oprócz tego część oddziałów korzystała z trasy Połock - Newel - Wielkie Łuki $^{49}$. Różne szlaki ciągnienia pozwalały na szybszy transport, łatwiejsze zaopatrzenie, a przede wszystkim pozwalały objąć w posiadanie mniejsze zamki leżące na uboczu głównego pochodu (Suraż, Uświat, Newel, Jezierzyce).

Na potrzeby wyprawy pod Psków (1581 r.) przygotowano aż sześć możliwych tras: z Dynenburga, drogę wodną „dla prowadzenia dział i statku” oraz trzy marszruty biorące swój początek z Wilna. Te ostatnie miały dwie trasy inflanckie i jedną prowadzącą przez Brasław, Dryssę, Siebież i Opoczkę, odnotowano również drogę, która została przygotowana na polecenie Iwana Groźnego podczas kampanii inflanckiej z 1577 r. ${ }^{50}$. Wybrano jeszcze inny wariant. Zachował się, zrealizowany plan trasy przemarszu dworu królewskiego wraz z wojskiem. Co najmniej w połowie czerwca 1581 r. przygotowano itinerarium zatytułowane Droga y noczlegi krola I.M. iadącz z Wilna do Połoczka, gdzie odnotowano miejsca postojowe począwszy od Wilna, a skończywszy na Zawołoczu - w sumie 17 punktów ${ }^{51}$. W zasadzie opis dzieli się ten na dwie nierówne części. Pierwsze 15 punktów to tereny dobrze znane i rozpoznane - częściowo trasa ta była wykorzystana w $1579 \mathrm{r}$. Widać to po bardzo precyzyjnym opisie nawet niewielkich miejscowości, które oddalone są od siebie o dzień drogi. Odległości wynoszą od 2 do 3,5 mili (w jednym przypadku 4 mile). Trasa taka prowadziła aż do Połocka. Na ziemi pogranicznej nie dysponowano tak precyzyjnymi informacjami. Odnotowano jedynie „Za dwa dni do Niesczardi s Połoczka - 10” [mil] i „Za drugie dwa dni z Niesczardi do Zawołocza - 12" [mil] ${ }^{52}$. Badania Marka Wredy dowodzą, że trasa Wilno-Dzisna była zaplanowana perfekcyjnie. Przemierzono ją zgodnie z opisem w 13 dni bez dodatkowych postojów i odpoczynku. Następnie trasa biegła według planu, ale już z długotrwałymi postojami (Dzisna 1-15 VII, Połock 15-21 VII). Ostatni

${ }^{49}$ Tenże, Wojsko polsko-litewskie. Część III, s. 93-99.

${ }^{50}$ Российская национальная библиотека, Санкт-Петербург, Ф. 971, Авт. 152, № 4, k. 1-1v; S. Alexand rowi cz: Rozwój kartografii, s. 193. Z 1579 r. znamy dwie inne trasy, których celem miał być Psków (z Kosicza, Kokenhauzen). Российская национальная библиотека, Санкт-Петербург, Ф. 971, Авт. 321/1, № 11, k. 18v-20;

51 [J. Piotrowski] do A. Opalińskiego, 20 VI 1581, [w:] Дневник последнего похода Стефана Батория на Россию (осада Пскова) и дипломатическая переписка того времени, относящаяся главным образом к заключению Запольского мира (1581-1582 г.), wyd. М. Коял ович, Санктпетербург 1867, s. 14: „Drogę у noczlegi possyłam Waszmości swemu Miłościwemu Panu". Droga y noczlegi krola I.M. iadącz z Wilna do Połoczka, [w:] Tamże, s. 220. Według M. Wre de, op. cit., s. 110: „rzeczywista marszruta króla tylko nieznacznie odbiegała od planu".

${ }^{52}$ Droga y noczlegi krola I.M. iadącz z Wilna do Połoczka, [w:] Tamże, s. 220. 


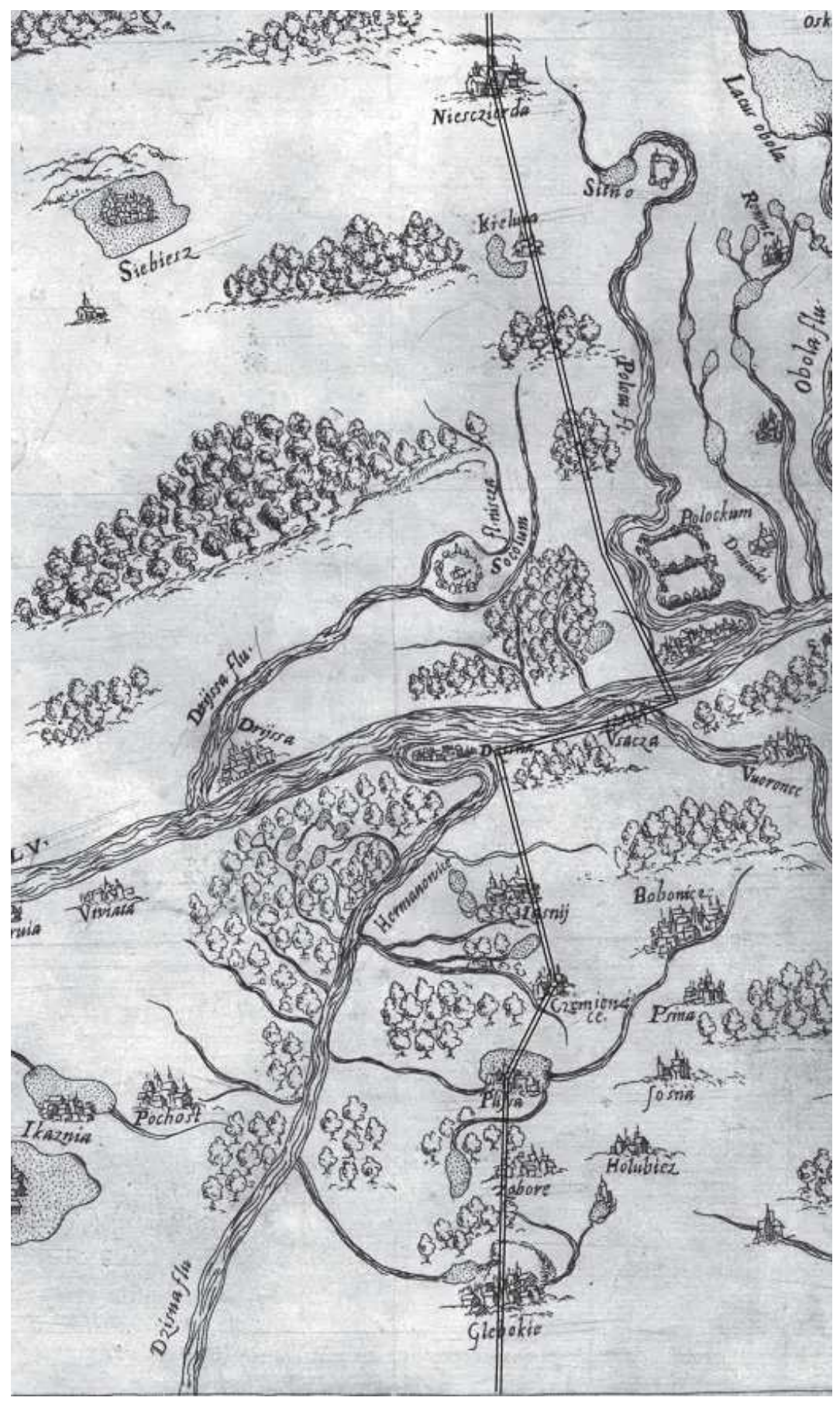

Il. 4. Mapa Stanisława Pachołowieckiego wykonana w 1579 r. (fragment) z naniesieniem drogi zaproponowanej w itinerarium z $1581 \mathrm{r}$. 
etap podróży również zajął przewidywany czas - dwa dni do Nieszczerdy i dwa kolejne do Zawołocza ${ }^{53}$. Można stwierdzić, że cały szczegółowy plan przygotowany jeszcze w czerwcu został w 100\% zrealizowany podczas marszruty. Dodać wypada, że ta niezwykła precyzja nie byłaby możliwa, gdyby nie istniały dwie mapy tych terenów: drukowana Stanisława Pachołowieckiego i rękopiśmienna Stanisława Sulimowskiego (zob. il. 4) ${ }^{54}$.

Wkraczając na ziemie nieprzyjacielskie, należało przygotować dalszy plan wyprawy, którego miejscem docelowym miał być Psków. Powstała wówczas interesująca forma pośrednia pomiędzy opisową formą trasy ciągnienia a mapą marszrutową. W Archiwum Watykańskim przechowywana jest itineraria picta zatytułowana Civitatis Plescoviensis delineatio (zob. il. 5) ${ }^{55}$. Stanisław Alexandrowicz za jej twórcę uznał Stanisława Pachołowieckiego ${ }^{56}$. Co prawda mapa została w dokumentacji papieskiej umieszczona obok listów datowanych na 25 października i 3 listopada $1581 \mathrm{r}^{57}$, ale Albert Bolognetti już 9 września 1581 r. informował o wykonaniu rysunku okolic Pskowa ${ }^{58}$. Prawdopodobnie jednak itinerarium powstało dużo wcześniej. Skłania mnie do tego jej układ. Istotne, że zaznaczono na trasie przemarszu obóz królewski. W zależności od interpretacji można przyjąć, że jest on położony przy Zawołoczu lub miejscowości Woroniec. Od miejsc tych wyznaczono trasę przemarszu i podano odległości.

W Zawołoczy kończyło się przygotowane w Wilnie itinerarium. W miejscu tym odbyło się doniosłe wydarzenie, a mianowicie obradowała tam 29 lipca 1581 r. rada wojenna. Na niej król z swoimi doradcami ustalali, „w który kąt się obrócić. Uchwalono, że do Pskowa. Do Nowogroda niebezpiecznie, boby Psków i kilka innych zam-

${ }^{53}$ M. Wrede: op. cit., s. 111-113.

${ }^{54}$ Zachowane egzemplarze mapy Descriptio ducatus Polocensis Pachołowieckiego: Bibliothèque Nationale de France, Coll. Lallemand de Betz, sygn. VX-48-FOL, fol. 198-199, n. 7454; Zamek Królewski w Warszawie - Muzeum, Kolekcja Tomasza Niewodniczańskiego, sygn. TN 2464, (dep. Deutsch-Polnische Stiftung Kulturpflege und Denkmalschutz); British Library, sygn. Maps *33825.(1.). Rękopiśmienna mapa Sulimowskiego przechowywana jest: Archivio Segreto Vaticano, Segreteria di Stato, Polonia, sygn. 15A, k. 88. Por. G. Fr a n cz a k: Filologia mapy. Badanie dawnej kartografiimetoda krytyki tekstu na przykładzie toponimii mapy Księstwa Połockiego S. Pachołowieckiego z 1580 roku, “Terminus" 19 (2017), 1, s. 205-206.

${ }^{55}$ Archivio Segreto Vaticano, Segreteria di Stato, Polonia, sygn. 18, k. 276. Została ona odnaleziona przez Karola Buczka w 1934 r., który źródło to omówił. K. Bu czek, Dorobek kartograficzny wojen Stefana Batorego, Warszawa 1934 [odbitka z „Wiadomości Służby Geograficznej" t. 8: 1934, z. 3], s. 8-9. Zob. M. Wred e: op. cit., s. 61.

${ }^{56}$ S. Alexand rowicz: Dziedzictwo kartografii wojskowej ziem Wielkiego Księstwa Litewskiego. Jej funkcje źródłowe i praktyczne na tle kartografii krajów Europy Wschodniej XVI i XVII wieku, [w:] Środowisko kulturotwórcze i kontakty kulturalne na tle Wielkiego Księstwa Litewskiego od XV do XIX wieku, Warszawa 2009, s. 202; S. Alexan drowicz: Kartografia Wielkiego Księstwa Litewskiego, s. 171.

${ }^{57}$ Archivio Segreto Vaticano, Segreteria di Stato, Polonia, sygn. 18, k. 275v, 277.

${ }^{58}$ Monumenta Poloniae Vaticana, t. V: Alberti Bolognetti nuntii apostolici in Polonia epistolarum et actorum pars 1 aa. 1581 - 1582, edd. E. Kuntze, Cz. N an ke, Kraków 1923-1933, s. 45. 
ków musielibyśmy po sobie zostawić”. Ustalono z jakich terenów będzie dochodziło zaopatrzenie (przez Rygę i Inflanty) oraz jak odległy jest punkt docelowy („mamy tu stąd Psków niedaleko, 30 mil, trzeba nam miec chodu mało nie dwie niedzieli") ${ }^{59}$. Informacje podane przez Jana Piotrowskiego, podobnie jak przykłady z lat wcześniejszych nie pozostawiają złudzeń, że do planowania wykorzystywano pomoce kartograficzne. Równie oczywiste jest, że po podjęciu decyzji należało wykonać dokładne rozpoznanie, tak aby można było sporządzić trasę przemarszu.

W mojej ocenie mapa powstała, gdy obóz królewski stacjonował już pod Worońcem. W miejscu tym 10 sierpnia wydano obowiązujące wszystkich żołnierzy artykuły wojskowe, a dwa dni później dokonano generalnego popisu i okazowania ${ }^{60}$. Warto dodać, że na itinerarium picta podano informację o spalonej twierdzy Krasny Horodek (Krasny Horodek a nostris combusta). Do obozu polskiego informacja o tym dotarła 9 sierpnia („Moskwa niedawno kilka dni temu zamek niedaleko Pskowa, Krasny Horodek, spaliła dobrowolnie sami i ze wszystkiem do miasta się znieśli") ${ }^{61}$. Około 10 sierpnia musiał więc powstać plan na bazie przeprowadzonego rozpoznania, który zweryfikował przyjętą drogę pod Zawołoczem. Nowe dane pozwoliły ustalić długość przemarszu na 36 mile ${ }^{62}$.

Centralne miejsce na itinerarium zajmuje miasto Psków, ukazano jego fortyfikację, a przede wszystkim odnotowano dwa zamki: wyższy i niższy. Zaznaczono rzeki: Wielikaja (Великая), Pskowa (Пскова), Seroth oraz niezidentyfikowaną na mapie rzekę, lewy dopływ Wielikiej, wpadający w wysokości Pskowa prawdopodobnie Mirożkę (Мирожка). Cechą charakterystyczną jest zaznaczenie odległości pomiędzy zamkami. Z Zawołocza do Worońca odnotowano 18 mil, z Worońca do zamku Ostrów 8 mil i dalej w dół rzeki Wielikiej aż do Pskowa kolejne 8 mil. Dodatkowo wskazano, że z Worońca do Opoczki (położonej po drugiej stronie rzeki Wielikiej) dzieli droga o długości 4 mil, a do Krasnego Horodku (jak informuje mapa spalonego) mil 7.

Opisy Piotrowskiego pokrywają się z wykonanym szkicem. 11 sierpnia pamiętnikarz odnotował, że „na drodze do Pskowa w pół drogi zamek moskiewski murowany, Ostra zowią", który będzie oblegany ${ }^{63}$. Rzeczywiście na mapie pomiędzy Woroneczem a Ostrowem odnotowano 8 mil i taką samą odległość od tego zamku do

\footnotetext{
${ }^{59}$ J. Piotrows ki: Dziennik wyprawy Stefana Batorego pod Psków, wyd. A. Czuczyński, Kraków 1894, s. 41; Дневник последнего похода, s. 41-42.

${ }^{60}$ Króla Stefana Batorego artykuły wszemu rycerstwu, obóz pod Worońcem 10 VIII 1581, [w:] Polskie ustawy i artykuły wojskowe od XV do XVIII wieku, oprac. S. Ku trzeba: Kraków 1937, s. 153-158; J. Piotrowski: dz. cyt., s. 48; K. Ło patecki, „Disciplina militarsi” $w$ wojskach Rzeczypospolitej do połowy XVII wieku, Białystok 2012, s. 231-236.

${ }^{61}$ J. Piotrowski: s. 45.

${ }^{62}$ Z pewnością inną mapę okolic Pskowa załączył w liście Possevino z 13 stycznia $1582 \mathrm{r}$. Possevino do kardynała Komy, Kiveroca Horka 14 I 1582, [w:] Monumenta Poloniae Vaticana, t. V, s. 174.

${ }^{63}$ J. Piotrowski: s. 47-48.
} 


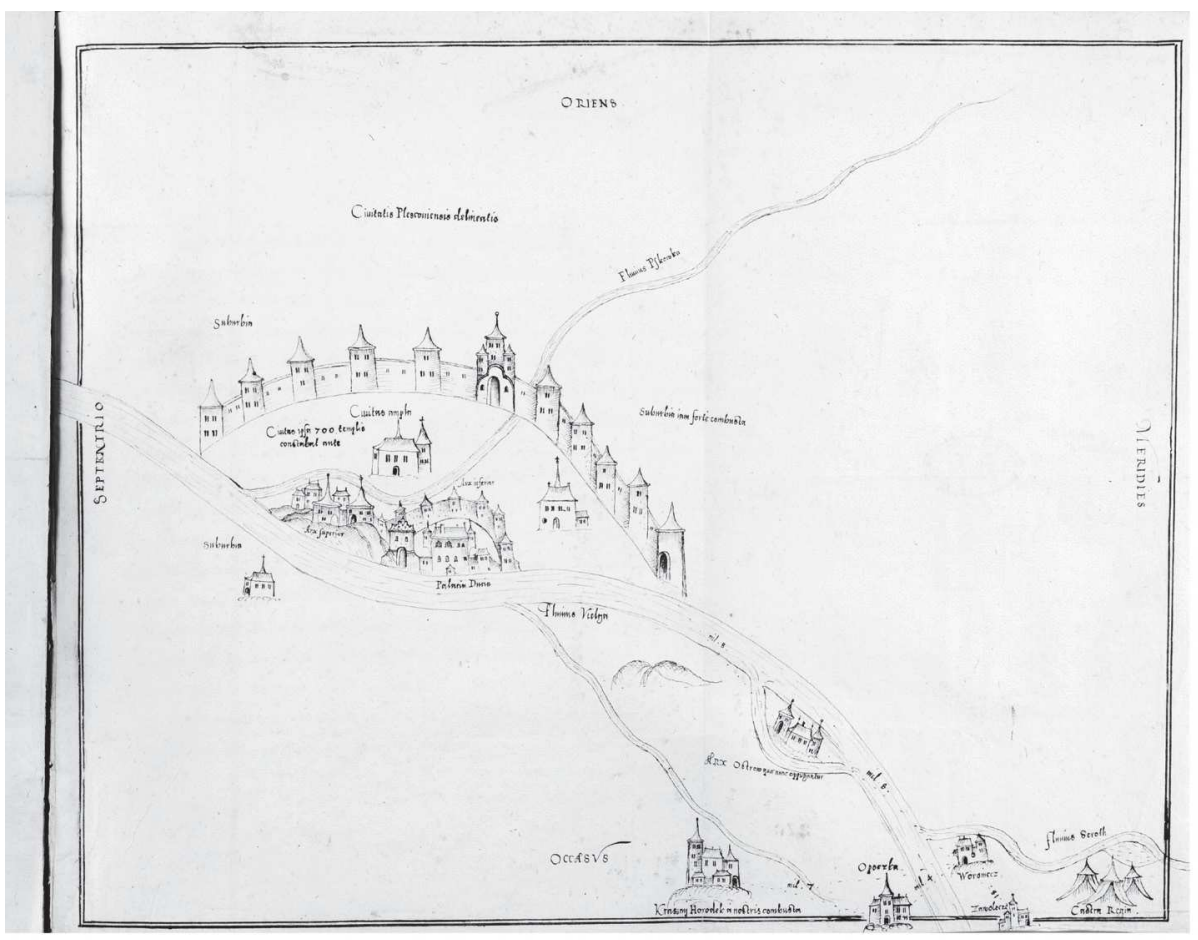

Il. 5. Itineraria picta (zatytułowana Civitatis Plescoviensis delineatio) prezentująca ostatni etap trasy przemarszu wojsk Stefana Batorego pod Psków (1581 r.) ${ }^{63}$

Pskowa. Odległości te zgadzają się z podanymi przez Jana Piotrowskiego (15-16 VIII armia przebyła 5 mil, 17 VIII 2 mile, do Ostowa tylko równa mila). Ponadto opis położenia zamku zgadza się z mapą: „zamek ten zbudowany jest na ostrowie w pół rzeki, wielki, murowany". Po zdobyciu umocnienie nieco modyfikuje swoje spostrzeżenia: „choć niewielki, ale osobliwy to zameczek. Woda ze wszech stron oblała wysepką, na której siedzi, wodę zaś Moskwa tak pod mury osobliwie gaciami ujęła i młynów owak po polsku nie mało pobudowała, że miło patrzeć" ${ }^{65}$. Oceniając to źródło należy stwierdzić, że poświadcza on o dobrym rozpoznaniu trasy przemarszu do Pskowa.

Podsumowując itineraria wykorzystywane w okresie panowania Stefana Batorego warto przytoczyć słowa Stanisława Alexandrowicza. Według niego mapy operacyjne Pachołowieckiego, czy Sulimowskiego należy ocenić jako „szkice kartograficzne dalekie od jakiejkolwiek precyzji”, jednakże zawierały dość szczegółowe informacje hydrograficzne i sieć osadniczą, co „w połączeniu z powszechnie wówczas stosowanymi itinerariami pisanymi (itineraria scripta) mogły z powodzeniem służyć planowaniu operacji wojskowych"66.

\footnotetext{
${ }^{64}$ Archivio Segreto Vaticano, Segreteria di Stato, Polonia, sygn. 18, k. 276. Ilustracja po raz pierwszy reprodukowana w pracy: K. B u czek, dz. cyt., tabl. II.

${ }^{65} \mathrm{~J}$. Pi otrows ki: s. 54, 57; Дневник последнего похода, s. 57.

${ }^{66}$ S. Alexandrowicz: Rozwój kartografii, s. 70.
} 
Na koniec warto dodać, że inny charakter miały wyprawy zagończyków w głąb terytorium nieprzyjacielskiego, które to działania nie mogły być ściśle zaplanowane czego najlepszym przykładem jest sławna wyprawa Krzysztofa Radziwiłła w 1581 r. w głąb państwa moskiewskiego ${ }^{67}$.

$$
\text { * * * }
$$

1. Itineraria wykonywane na potrzeby wojskowe dzielą się na opisy przebytego szlaku (stanowiące dokumentację z wyprawy) oraz na plany przyszłych działań militarnych. Ten drugi rodzaj dokumentów pozwala odtworzyć nie tylko koncepcje strategiczną, ale również operacyjną (manewrową) naczelnego wodza/rady wojennej. Oprócz tego występują itineraria scripta oraz itineraria picta (zob. odpowiednio il. 2-3 i il. 1,5). Pierwsze miały charakter opisowy, drugie wzbogacone były wyobrażeniem ikonograficznym, czego przykładem jest plan ciągnienia wojsk pod Psków w 1581 r. Oprócz tego na mapach zaczęto nanosić ciągi miejscowości, które pierwotnie odnotowane były jako trasy opisane w formie itinerariów (zob. il. 4).

2. Itineraria tworzone przez wodzów prowadziły do uporządkowania wiedzy przestrzennej i ustalenia podstawowych założeń wyprawy. Określano wówczas planowaną odległość przemarszu wojsk, tym samym w przybliżeniu oceniano ile dni potrwa dotarcie do celu. Warto podkreślić, że precyzja planowania marszrut dziennych podczas wyprawy pod Psków w 1581 r., była zrealizowana w 100\% (zob. il. 4).

3. Początek i rozwój itinerariów jako planowanych tras przemarszu należy wiązać z wykształceniem się pułków jako niezależnych zgrupowań wojsk. Przygotowywane trasy stanowiły podstawę współdziałania i koordynacji pomiędzy pułkami (zob. il. 3). Początek tego zjawiska możemy dostrzec wraz z przybyciem do Inflant wojsk koronnych pod dowództwem Floriana Zebrzydowskiego. Tym samym na jednym obszarze geograficznym (Inflanty, Połocczyzna, Witebszczyzna) operowały dwie sojusznicze armie (polska i litewska), które musiały koordynować swoje poczynania, co wyraźnie widoczne było już w roku 1562.

4. Najstarszym zachowanym źródłem planowanych szlaków wojennych jest Wiadomość kędy w ziemię nieprzyjacielska iść, która pochodzi z około 1570 r. Zawiera ona dwie trasy z Kiesi (Wenden) - jedną prowadzącą na wschód, aż po Monaster Pskowsko-Pieczerski, drugi zaś prowadzący na północny zachód z Dźwinoujściem jako punktem docelowym (zob. il. 2). Oceniam jednak, że „wczesnonowożytny zwrot kartograficzny" rozwinął się w Rzeczypospolitej dopiero w początkowym okresie panowania Stefana Batorego, przełomem w myśleniu przestrzennym wodzów były lata 1579-1582.

${ }^{67} \mathrm{R}$. Krzywy: „Chcesz być groźnym, a uciekasz...”: nad komentarzem do epinikionów moskiewskich Jana Kochanowskiego, t. 104: 2013, z. 3, s. 187-191 
5. W czasach Stefana Batorego itineraria wykorzystywano już powszechnie w momencie koncentracji wojsk oraz podczas rozchodzenia się oddziałów na leża zimowe. Roty pojedynczo albo zgrupowane w pułki otrzymywały szczegółową trasę przemarszu. Miało to na celu zapewnienie żołnierzom drogi najszybszej do pokonania, a jednocześnie gwarantującą sprawną aprowizację. Istotnym celem takich działań było ulżenie ludności cywilnej poprzez rozproszenie tras przemarszu. Pojawiło się również zjawisko wydzielenia pułków na dwie części podążające po tej samej marszrucie, pierwsza poprzedzała drugą o dzień drogi.

6. Zastosowanie itinerariów na potrzeby planowania strategicznego i operacyjnego było szeroko wykorzystywane w przez dowództwo polsko-litewskie w okresie batoriańskim. W szczególności doskonały rezultat przyniosła zimowa wprawa Krzysztofa Radziwiłła „Pioruna” do Dorpatu w 1579 r. Stworzono wówczas trzy pułki, które miały oddzielne, lecz skoordynowane trasy przemarszu. Akcja ta zaskoczyła Rosjan i nie tylko udało się spustoszyć rozległe tereny pogranicza, to dodatkowo zdobyto zamek Kierepeć (zob. il. 3). Itineraria wykorzystywano również podczas rad wojennych - przykładowo w Świrze w 1579 r., czy pod Worońcem w 1581 r. (zob. il. 5). Wydzielenie pułków podczas operacji wojskowych umożliwiało szybsze ciągnienie, łatwiejsze zaopatrzenie, ale także pozwalało uzyskać inicjatywę operacyjną, co było elementem kluczowym podczas wojny.

\section{BIBLIOGRAFIA}

Alexandrowicz S.: Dziedzictwo kartografii wojskowej ziem Wielkiego Księstwa Litewskiego. Jej funkcje źródłowe i praktyczne na tle kartografii krajów Europy Wschodniej XVI i XVII wieku, [w:] Środowisko kulturotwórcze i kontakty kulturalne na tle Wielkiego Księstwa Litewskiego od XV do XIX wieku, Warszawa 2009.

Al exandrowicz S.: Kartografia Wielkiego Księstwa Litewskiego od XV do połowy XVIII wie$k u$, Warszawa 2012.

Alexandrowicz S.: Kartografia wojskowa Wielkiego Księstwa Litewskiego do połowy XVII wieku, [w:] Kartografia wojskowa krajów strefy bałtyckiej XVI-XX w., red. S. Al exandrowicz, Z. Karpus, W. Rezmar, Toruń 1996.

Alexandrowicz S.: Rozwój kartografii Wielkiego Księstwa Litewskiego od XV do połowy XVIII wieku, Poznań 1989.

Alexandrowicz S., Buczek: K. Polska kartografia wojskowa do połowy XVII wieku, [w:] Dzieje polskiej kartografii wojskowej i myśli strategicznej. Materiały z konferencji, oprac. B. Krassowski, J. Madej, Warszawa 1982.

Alexandrowicz S., Łuczyński J., Skrycki R.: Historia kartografii ziem polskich do końca XVIII wieku, Warszawa 2017.

Almonaitis V.: Laukuvos apylinkès kryžiuočiu karo kelių aprašymu duomenimis, [w:] Laukuva. Lietuvos valsčiai I, Vilnius 2005.

Bagrow L.: History of Cartography, New Brunswick-London 2010. 
Buczek K.: Dorobek kartograficzny wojen Stefana Batorego, Warszawa 1934 [odbitka z „Wiadomości Służby Geograficznej” 8 (1934), 3].

Englisch B.: Erhard Etzlaub's Projection and Methods of Mapping, "Imago Mundi" 48 (1996).

Ferenc M.: Mikołaj Radziwiłł „Rudy” (1515-1584), Kraków 2008.

Fran czak G.: Filologia mapy. Badanie dawnej kartografii metoda krytyki tekstu na przykładzie toponimii mapy Księstwa Połockiego S. Pachołowieckiego z 1580 roku, „Terminus” 19 (2017), 1.

Gąsiorowski A.: Itineraria dwu ostatnich Jagiellonów, „Studia Historyczne” t. 16: $1973 \mathrm{nr} 2$.

Hal e J.: Warfare and Cartography, ca. 1450 to ca. 1640, [w:] The History of Cartography, vol. 3, Chicago 2007.

Hermann H.: Operacyjny wymiar walki zbrojnej, Toruń 2004.

Korzon T.: Dzieje wojen i wojskowości w Polsce, t. II, Kraków 1912.

Kossarzewski K., Szyller S.: Rękopisy Biblioteki Załuskich w Sankt Petersburgu, „Rocznik Biblioteki Narodowej" t. 44: 2013.

Kotarski H.: Wojsko polsko-litewskie podczas wojny inflanckiej 1576-1582. Sprawy organizacyjne. Część III, „Studia i Materiały do Historii Wojskowości” t. 17: 1971 nr 2.

Kotarski H.: Wojsko polsko-litewskie podczas wojny inflanckiej 1576-1582. Sprawy organizacyjne. Część IV, „Studia i Materiały do Historii Wojskowości” t. 18: 1972 nr 1.

Kotarski H.: Wojsko polsko-litewskie podczas wojny inflanckiej 1576-1582. Sprawy organizacyjne. Część II, „Studia i Materiały do Historii Wojskowości” 17 (1971), 1.

Krzywy R.: „Chcesz być groźnym, a uciekasz...”: nad komentarzem do epinikionów moskiewskich Jana Kochanowskiego, t. 104: 2013, z. 3.

Kupisz D.: Połock 1579, Warszawa 2003.

Kwiatkowski K.: Wojska zakonu niemieckiego w Prusach 1230-1525 (korporacja, jej pruskie władztwo, zbrojni, kultura wojny i aktywność militarna), Dzieje Zakonu Niemieckiego, t. 3, Toruń 2016.

Lesmaitis G.: Wojsko zaciężne w Wielkim Księstwie Litewskim w końcu XV - drugiej połowie XVI wieku, tłum. B. Piasecka, Warsza wa 2013.

Lulewicz H.: Radziwiłł Krzysztof zwany Piorunem, [w:] Polski słownik biograficzny, t. XXX, Wrocław 1987.

Łabędź P.: Działalność wojskowa Krzysztofa Radziwiłła „Pioruna” w latach 1572-1579, „Zapiski Historyczne” t. 76: $2011 \mathrm{nr} 1$.

Łopatecki K.: „Disciplina militarsi” w wojskach Rzeczypospolitej do połowy XVII wieku, Białystok 2012.

Łopatecki K.: Wyprawa zbrojna Krzysztofa Radziwiłła „Pioruna” w Inflantach zimq 1579 roku, „Zapiski Historyczne” t. 83: $2018 \mathrm{nr} 1$.

Plewczyński M.: Wkład Radziwiłłów w rozwój staropolskiej sztuki wojennej XVI w., „Miscellanea Historico-Archivistica” 7 (1997).

Polak A.: Sztuka wojenna. Kontekst teoretyczny i praktyczny, „Zeszyty Naukowe AON” 92 (2013), 3.

Rad och M.: Die littauischen Wegeberichte jako źródło wiedzy geograficznej w Zakonie Krzyżackim o ziemiach Wielkiego Księstwa Litewskiego, [w:] Nauki pomocnicze historii. Teoria, metody badań, dydaktyka, red. A. Jaw orska, R. Jop, Warszawa 2013. 
Rott D.: Staropolskie chorografie, Katowice 1995.

Török Z.G.: Renaissance Cartography in East-Central Europe, ca. 1450-1650, [w:] The History of Cartography, vol. 3, Chicago 2007.

Węcowski P.: Polskie itineraria średniowieczne i nowożytne: przegląd badań i propozycje badawcze, „Studia Źródłoznawcze” R. 37: 2000.

Wrede M.: Itinerarium króla Stefana Batorego 1576-1586, Warszawa 2010.

Wy tyczak R.: Śląsk w dawnej kartografii. Obraz Ślaska na mapach XVI-XVIII wieku w zbiorach Zakładu Narodowego im. Ossolińskich we Wrocławiu, Wrocław 1998.

Zieliński J.: Zarys teorii sztuki operacyjnej wojsk lądowych Rzeczpospolitej Polskiej, Toruń 1998. 